\title{
A comparative analysis between liberal democracy and the China and Vietnam model's voting system
}

\author{
Manh-Tung Ho ${ }^{1,2,3}$ \\ ${ }^{1}$ Ritsumeikan Asia Pacific University, Beppu, Oita Prefecture, 874-8577, Japan \\ ${ }^{2}$ Institute of Philosophy, Vietnam Academy of Social Sciences, 59 Lang Ha St., Hanoi, 1- \\ 100000, Vietnam \\ ${ }^{3}$ AI for Social Data Lab, Vuong \& Associates, Hanoi, 100000 Vietnam \\ Email: tungmanhho@gmail.com
}

\section{Abstract}

The current rise of populism in many democracies all over the world has raised questions about the ability of the "one person, one vote" system to produce the most competent leaders. Though the rise of populism is a recent phenomenon, many philosophers and political scientists in the past have questioned the wisdom of "one person, one vote" and proposed the alternative. In this paper, some of the arguments against liberal democracy's voting system will be explored, followed by the model of China and Vietnam for choosing political leaders. These two countries, known for the ability to maintain an impressive level of economic growth consistently, can be argued to present an alternative to the liberal democracy's way. Whether the China (Vietnam) model is a viable option is an issue worthwhile of ethical consideration.

Keywords: "one person, one vote"; liberal democracy; political meritocracy; the China (Vietnam) model 


\section{Introduction}

In recent years, the world has witnessed an unprecedented rise of populism and populist politicians in all kinds of democracies from the Philippines, France, Italy, to the United States, to name a few (Bröning, 2016). The rise of populism has been causing so much uncertainty in the lives of the

citizens in these countries and the world. Together with the fact that countries like China and Vietnam have maintained an impressive level of socio-economic performance over the past three decades (Vuong, 2014, 2019a), this phenomenon has created an intense interest in the debate on whether Western liberal democracy or the meritocracy in China and Vietnam is better in choosing competent and virtuous leaders (Lim, 2012; Volodzko, 2015; Eichengreen \& Yu, 2018). In this paper, I will explore some of the arguments for and against the "one person, one vote" system and present the China or Vietnam model of choosing political leaders as a possible alternative.

\section{Theoretical background}

The most famous defense of political participation is from the British philosopher John Stuart Mill who hypothesized that political participation would serve as an education for the citizens and they will become smarter and make better choices over time (Mill, 1977; Mutz, 2006; McCelod, 2016). Although Mill is cautious against the problem of the tyranny of the majority, he thinks that the utility of political participation added to the life of the individual citizen is worth more than its risk.

In contrast, the philosopher and economist Joseph Schumpeter disagrees strongly with Mill, he thinks rather than ennobling the people, political participation tends to corrupt us. Here, Schumpeter articulates the problem: 
"The typical citizen drops down to a lower level of mental performance as soon as he enters the political field. He argues and analyzes in a way which he would readily recognize as infantile within the sphere of his real interests. He becomes a primitive again.” (Schumpeter, 1996, p.262).

Mill hypothesized about the effects of democratic participation over 150 years ago. His hypothesis relied on the assumption that over time, people will be able to change their mind rationally. Recent developments in neuroscience and psychological sciences have shown that it is notoriously difficult for people to change their mind and the way people reason is not precisely rational, to say the least. Many studies show that when being presented with evidence that contradicts firmly held beliefs, people tend to discount the evidence (Haidt, 2012; Wright, 2017; Kaplan, Gimbel \& Harris, 2016). The seminal work in behavioral economics of Kahneman and Tversky shows that far from being rational, people engage in all sort of heuristics when it comes to reasoning: confirmation bias, junk cost fallacy, motivated reasoning, etc. (Kahneman, 2011).

\section{Some arguments against “one person, one vote"}

In light of the arguments above about the results of political participation and the evidence on the flawed way people reason, recently, scholars have tried to build a stronger empirical case against the liberal democracy voting system. Political scientist, Daniel H. Bell (2016) argued that the implicit assumption that "one person, one vote" system is the only moral way to set up the electoral process should be challenged. In his book, The China Model, he explained the significant issues with the liberal voting system as follows. The critical problem is that most voters lack the knowledge necessary to make informed political choices. The reason for this lack of political knowledge is not just a lack of time. It goes deeper, as put by the political philosopher Jason Brennan, it is rational for the citizens to be ignorant of politics as individual voters' choices matter very little over the government and acquiring political knowledge is very costly and challenging 
(Brenan, 2012). Thus, lack of time and motivation prevent voters from gaining sufficient knowledge to make informed political judgments.

However, it is not just time and motivation that are the problem; it is also the cognitive biases that are inherent in many of us as shown by decades of psychological and neuroscientific research (Kahneman, 2011). Bell, then, presented the empirical evidence on the ignorance of the voters in the U.S: $79 \%$ of the voters have no ideas who their senators are, some $19 \%$ of them believe in conspiracy theories about 9/11 attacks (Brennan, 2012) or a poll in 2005 found that 22\% of the respondents think the three branches of the government were "Republican, Democrat and Independent" (Goldberg, 2013).

Given the problem with voter's lack of knowledge, philosopher Jason Brennan attempted to differentiate three kinds of voters: The Hooligans, the Hobbits, and the Vulcans. The Hooligans are passionate about politics but see politics as a sporting event, where they vote only to the people they consider to be on their side. The Hobbits, on the other hand, are chill and relax; they simply do not care enough about politics to give it enough thoughts. They can see no problem switching between one political stance to another, and most of the time even are not aware of the switch. The Vulcans are rational being; they will listen to both sides of the argument, make their choices based on the best available, and they are willing to change their mind if new facts are convincing enough. Brennan argued that the majority of the voters are some combination of the Hooligans and the Hobbits (Brennan, 2017; Brennan, 2009).

And from here, he argued against liberal democracy's voting system by a thought experiment: the Grand Jury thought experiment, in which, he argued for the right to competent voters. When you are trialed in Court, the consequences of the decision of the grand jury is genuinely significant: in the extreme case, you can be sent to death or jail for life or be free. It is 
therefore natural that you want to have a fair-minded and competent jury, people who have the traits of the Vulcans. In the case of an election, the choice the voters make are very significant and can change the course of the country or even the world for better or worse. If in the case of the trial, people have the right to a competent jury, why do we collectively not have the right for competent voters? However, the truth is, more often than not, democratic voters are ignorant and biased on crucial issues. Thus, we should rethink the "one person, one vote" system.

These empirical and theoretical cases for rethinking the "one person, one vote" system bring us to the discussion of an alternative: the China or Vietnam model of choosing political leaders.

\section{The China or Vietnam model}

The China or Vietnam model goes by different names in different contexts: democratic centralism (Yang, 2016) or vertical democratic meritocracy or political meritocracy (Bell, 2016). But what are the main characters of this model? Bell (2016) articulated the ideal of this model as follows. In the lowest level of government, the election of political leaders is as democratic as possible. People don't choose among political parties but they choose from people the local citizens have nominated; the candidates that the local people know personally and feel that they can trust with making policies and listen to their voices. Then these elected officials in the grassroots level will choose their leaders based on the performances of the candidates.

In the highest level of government where the leaders often have to deal with very complex and unpopular choices, the election of political leaders is ideally as meritocratic as possible, and the people who judge the merits of the next leaders are the insiders of the power structure. Here 
also, the similarity with the election in the citizens level is that the people must know and trust their future leader's competency and character personally.

Another notable feature of the China or Vietnam model is the freedom to experiment in between the lowest and highest levels of government. For example, before being eligible for the nomination in the higher level of leadership, politicians in China and Vietnam are subject to being moved and tested their ability to lead in cities or provinces that they are not initially from. They must perform competently to be eligible as a nominee to the next level. This is often called "the grooming system" (Jiang, 2013; Chapman, 2018) and it is hoped that the experiences that the politicians gained from this process of having their political ability and leadership tested thoroughly will shape them into more competent and perhaps even virtuous leaders. Xi Jingpin, the President of China, before arriving in his current powerful seat, had won 16 promotions in all level of governments: township, province, cities. Xi was responsible for the economic performance of key cities in China such as Fujian and Shanghai; it is not irrational to assume that these experiences must have helped Xi enormously when he took the responsibility of being China's leader.

\section{A note of caution}

To discuss the merits of the model in either China or Vietnam for choosing political leaders, to be fair, one must not forget to make explicit certain facts. We don't yet know the full effects of the rise of populism to the stage of the world. It is clear there is so much uncertainty, and there are gloomy predictions about the impact of more populist politicians are coming into powers, but the truth is still nobody knows for sure whether this phenomenon is on balance a positive thing or not. Moreover, it is very important to note that China and Vietnam are two countries with so much cultural and historical similarities: successful nationalist-communist revolutions against 
imperialism lending legitimacy to the one-party rule, a culture of Three Great Religious teachings (Buddhism, Taoism, and Confucianism), Confucian ideals of public morality, etc. (Vuong et al., 2018; Vuong, Vuong, Nguyen \& Ho, 2019; Nguyen \& Ho, 2019), hence, the model of choosing political leaders could be imbued with both historical and cultural legitimacy. Another factor to consider is both countries are considered by the West to be disrespectful of human rights and freedom of press (Freedom House, 2018), though many researchers have started to question the framework of human rights coverage (Brooten, 2015). It is crucial to keep these facts in mind and not hastily jump into a conclusion about the success of different models of choosing leaders.

\section{Conclusions}

The ideals of the China or Vietnam model for choosing political leaders clearly have their appeals. However, in practice, the ideals are often not realized. Like liberal democracy, the model faces the same problem with fighting corruption. Moreover, Bell (2016) presented three other theoretical problems with the model: (1) how to prevent meritocratically chosen leaders from abusing their power, (2) how to maintain social mobility in a highly hierarchical political system, (3) how to give legitimacy to the chosen leaders for the normal citizens who are outside of the power structure. It is clear that the China model, in theory, and practice, is imperfect; but so is liberal democracy. Therefore, it is vital for scientists and serious thinkers to be open-minded when investigating the essential questions of political philosophy in the twenty-first century: What are the moral standards we should apply to judge the legitimacy of different types of political regime? And more generally, what are the future of political economy in East Asia? As the costs of failing to raise these genuine philosophical and even scientific questions would be calamitous (Vuong, 2019b). 


\section{References}

Beeson, M., \& Pham, H. H. (2012). Developmentalism with Vietnamese characteristics: the persistence of state-led development in East Asia. Journal of Contemporary Asia, 42(4), 539-559.

Freedom House. (2018). Freedom in the world 2018: Democracy in Crisis. Freedom House. Retrieved from https://freedomhouse.org/report/freedom-world/freedom-world-2018

Freedom House (2018). China Profile. Freedom House. Retrieved 17 May 2018 from https://freedomhouse.org/report/freedom-world/2018/china

Bell, D. A. (2016). The China model: Political meritocracy and the limits of democracy. Princeton University Press.

Brennan, J. (2009). Polluting the polls: When citizens should not vote. Australasian Journal of Philosophy, 87(4), 535-549.

Brennan, J. (2012). The ethics of voting. Princeton University Press.

Brennan, J. (2017). Against democracy. Princeton University Press.

Goldberg, J. (2013). Public Lacks Grasp of Obamacare. USA Today.

Haidt, J. (2012). The righteous mind: Why good people are divided by politics and religion. Vintage.

Kahneman, D. (2011). Thinking, fast and slow. Macmillan.

Kaplan, J. T., Gimbel, S. I., \& Harris, S. (2016). Neural correlates of maintaining one's political beliefs in the face of counterevidence. Scientific Reports, 6, 39589.

Mill, J.S. (1977). Considerations on Representative Government [orig. pub. 1861], in Collected Works of John Stuart Mill, ed. Robson, J. M. Toronto: University of Toronto Press, 1977, ch. 3.

Mutz, D. C. (2006). Hearing the other side: Deliberative versus participatory democracy. Cambridge University Press. 
Schumpeter, J. (1996). Capitalism, Socialism, and Democracy. New York: Routledge Press.

Wright, R. (2017). Why Buddhism is True: The Science and Philosophy of Meditation and Enlightenment. Simon and Schuster.

Vuong, Q. H. (2019a). The financial economy of Viet Nam in an age of reform, 1986-2016. In U. Volz, P. Morgan \& N. Yoshino (Eds.), Routledge Handbook of Banking and Finance in Asia (pp. 201-222). London, UK: Routledge (T\&F). DOI: https://doi.org/10.4324/9781315543222-12.

Vuong, Q. H. (2014). Vietnam's political economy: a discussion on the 1986-2016 period. WP-CEB $N^{\circ} 14-010$. Universite Libre de Bruxelles.

Vuong, Q. H., Bui, Q.K., La, V.P., Vuong, T. T., Nguyen, V. H., Ho, M. T., Nguyen, T. H. K., Ho, M. T. (2018). Cultural additivity: Behavioural insights from the interaction of Confucianism, Buddhism, and Taoism in folktales. Palgrave Communications, 4, 143. DOI: https://doi.org/10.1057/s41599-0180189-2.

Vuong, Q. H., Vuong, T.T., Nguyen, T.H.K. \& Ho, M.T. (2019). The 'same bed, different dreams' of Vietnam and China: how (mis)trust could make or break it. European Journal of East Asian Studies 18(1): 93128; doi:10.1163/15700615-01801007.

Vuong, Q.H. (2019b). Breaking barriers in publishing demands a proactive attitude. Nature Human Behaviour 3(10): 1034. doi: 10.1038/s41562-019-0667-6.

Vuong, Q.H. (2018). The (ir)rational consideration of the cost of science in transition economies. Nature Human Behaviour 2(1): 5, https://doi.org/10.1038/s41562-017-0281-4.

Nguyen, Tai Dong \& Ho, M. T. (2019). People as the Roots (of the State): Democratic Elements in the Politics of Traditional Vietnamese Confucianism. Journal of Nationalism, Memory \& Language Politics, 13(1), 90-110.

Yang, G. (2016). Still a Century of the Chinese Model? Exploring Dimensions of Democratic Centralism. Chinese Political Science Review, 1(1), 171-189. 
Lim, L. (2012, Nov 03). Who Picks Better Leaders: China Or The U.S.?. NPR The two-way. Retrieved from https://www.npr.org/sections/thetwo-way/2012/11/03/164171900/who-picks-better-leaders-china-or$\underline{\text { the-u-s }}$

Jiang, C. (2013, Oct 17). China's Viral Video on How to Be a Leader. Time. Retrieved 2018 May 25 from:

Volodzko, D. (2015, Oct 31). China's Meritocracy Vs. Western Democracy. The Diplomat. Retrieved from https://thediplomat.com/2015/10/chinas-meritocracy-vs-western-democracy/

Tiezzi, S. (2016, Jan 28). Vietnam's Party Chief Nguyen Phu Trong Keeps His Post. The Diplomat. Retrieved from https://thediplomat.com/2016/01/vietnams-party-chief-nguyen-phu-trong-keeps-his-post/

McCleod, C.(2016, Aug 25). John Stuart Mill. Stanford Encyclopedia of Philosophy. Retrieved from: https://plato.stanford.edu/entries/mill/\#AuthDemo

Eichengreen, B. \& Yu, P.H. (2018, May 10). Debate| The China Model. Project Syndicate The Big Picture. Retrieved from https://www.project-syndicate.org/bigpicture/debate-the-china-model

Chapman, No. (2018, May 15). The Beginning of a Political Doi Moi? Takeaways From the VCP's Seventh Plenum. The Diplomat. Retrieved from https://thediplomat.com/2018/05/the-beginning-of-a-politicaldoi-moi-takeaways-from-the-vcps-seventh-plenum/ 